\title{
SKRIFGEBRUIK IN PRAKTIES-TEOLOGIESE SPANNINGSVELDE / USING SCRIPTURE IN PRACTICAL-THEOLOGICAL TENSION-FIELDS
}

Author:

F.W. De Wet

\section{Affiliation:}

School for Biblical

Counselling and Church

Ministry

Noordwes-Universiteit, Potchefstroomkampus

\section{Correspondence to:}

F.W. De Wet

Email:

fritz.dewet@nwu.ac.za

\section{Postal address:}

727 27th Avenue, Villieria 0186, Pretoria, South

Africa

\section{Dates:}

Accepted: 01 Jun. 2015

Published: 01 Sep. 2015

How to cite this article: De Wet, F.W., 'Skrifgebruik in prakties-teologiese spanningsvelde', KOERS - Bulletin for Christian Scholarship 80(1), Art. \#2205, 12 pages. http:// dx.doi.org/10.19108/ koers.80.1.2205

\section{Copyright:}

(c) 2015. The Author(s). Published under the Creative Commons Atribution License.
In this article the author makes a case for a Sola Scriptura point of departure as an adequate instrument for shining the light of the Word of God not only on the surface level of a practical theological research field, but also on its depth level. It is argued that a Sola Scriptura point of departure does not only involve the biblical text on its own, but also a living relationship with The God who reveals Himself in Scripture. This point of departure entails that the researcher will not only deploy Scripture on the surface level as a mere formal prescriptive source for what ought to happen in the research field. Scripture will also be utilized at the depth level of the research field as a means by means of which the underlying motifs that may be present in the tension field of a particular practical-theological research area are unlocked. This method of using Scripture works with the following faith-expectations: That motifs and actions in a particular tension field will under the guidance of the Spirit - be brought into living contact with the One in whom the fullness of the Word of God is revealed, namely Jesus Christ; that disintegrative forces at work in the tension field will be brought into contact with the integrative presence of Jesus Christ, unlocking the reformational power of the Word of God in the process.

Key terms: Using Scripture, Sola Scriptura, Practical-theological research, Tension fields

In hierdie artikel beredeneer die outeur die waardevan `n Sola Scriptura-vertrekpunt as toereikende instrumentom dieligvan die Woordvan God nie alleen op die oppervlaktevan `n prakties-teologiese ondersoekveld te laat skyn nie, maar ook tot in die dieptevlak daarvan. Dit word beredeneer dat die Sola Scriptura-vertrekpunt nie alleen die bybelse teks opsigself behels nie, maar ook `n lewende verhouding met die God van die Woord by die ondersoekproses betrek. Hierdie benaderingswyse impliseer dat die navorser nie die Skrif bloot op die oppervlakte van die ondersoekproses sal betrek as ` $n$ formele voorskriftelike bron van wat behoort te gebeur in die ondersoekveld nie. Die Skrif sal ook op die dieptevlak van die ondersoekveld gerig word as ` $n$ ontsluitingspunt vir onderliggende motiewe wat in die prakties-teologiese ondersoekveld teenwoordig mag wees. Hierdie metode van Skrifgebruik werk met die volgende geloofsverwagtings: Dat motiewe en handelinge wat waargeneem word in ' $n$ bepaalde spanningsveld onder leiding van die Gees in lewende kontak gebring word met die Een waarin die volheid van die Woord van God geopenbaar word, naamlik Jesus Christus; dat disintegrerende kragte wat aan die werk is in die spanningsveld in kontak gebring word met die integrerende teenwoordigheid van Jesus Christus, sodat die reformerende krag van die Woord in die proses ontsluit kan word.

Sleutelterme: Skrifgebruik, Sola Scriptura, Prakties-teologiese ondersoek, Spanningsvelde 


\section{INLEIDING}

Dit is gepas dat ons by ' $\mathrm{n}$ geleentheid soos hierdie ${ }^{1}$ reflekteer oor ons reformatoriese erfenis en die implikasies daarvan vir die uitdagings waarmee ons in kontemporêre wetenskapsbeoefening te doen het. "Sola Scriptura" (Die Skrif alleen) is een van die mees kenmerkende slagspreuke van die sestiende eeuse Reformasie en hierdie geloofsuitspraak het sedert die ontstaan van ons universiteit ${ }^{1}$ ' $n$ wesenlike invloed uitgeoefen op die manier waarop die Skrif as bron van lig vir ons wetenskapsbeoefening beskou en hanteer is. Deur die lig van die Skrif op wetenskaplike ondersoekvelde te laat val - so glo ons - word ons denke verruim deur God se geopenbaarde bedoeling met die werklikheid en word ons teoretiese oorwegings normatief gefokus op 'n manier wat ons by perspektiefryke en begronde bevindings kan laat uitkom.

Skrifgebruik moet egter - soos enige wetenskaplike instrument - op ' $n$ verantwoordelike wyse en met ' $n$ aanvoeling vir die doel waarvoor dit aan ons toevertrou is, aangelê word. Onakkurate en oorvereenvoudigde gebruik van die Skrif in die gerigtheid daarvan op die werklikheid kan tot eensydige, eendimensionele en onwetenskaplike resultate aanleiding gee.

Op die navorsingsterrein van die Praktiese Teologie 'n ondersoekterrein waarin daar nie alleen gefokus word op die teks van die Bybel nie, maar ook nagedink word oor die mate waarin menslike handelinge ' $n$ weerspieëling is van Skrifbepaalde denke - blyk verantwoordelike Skrifgebruik geen onproblematiese saak te wees nie. Ballard (2012:163) beskryf hoe ' $n$ teks-gesentreerde inkleding van die Sola Scripturavertrekpunt in ' $\mathrm{n}$ polariserende spanning te staan kan kom met `n meer konteks-in-agnemende benadering van Skrifinterpretasie:

In Protestantism, with its slogan of Sola Scriptura, the Bible stands over the church and its meaning is received through the work of the Holy Spirit. However, there is a tension, especially in Protestantism, between a more conservatist (even fundamentalist) emphasis on the priority and literal authority of the scriptures and more liberal interpretation that reads the Bible in relation to contemporary insights and culture.

In ' $\mathrm{n}$ reaktiewe hantering van die verhouding tussen koersaanduidende Skrifgesag aan die een kant en komplekse verstaansmoontlikhede wat aan die ander kant deur besinning en ondersoek in kontemporêre empiriese konteks oopgemaak word, kan dit gebeur dat die Skrif so gebruik word dat dit voorafgeformuleerde waarhede en oorvereenvoudigde antwoorde

Verwerkte weergawe van die sk-rywer se intreerede gelewer met die oog op die aanvaarding van 'n professoraat in Praktiese Teologie aan die Fakulteit Teologie van die Noordwes-Universiteit, Potchefstroomkampus, 31 Oktober 2013.

1. Met verwysing na die Noordwes-Universiteit se historiese wortels, soos dit in die kenmerkende Christelike wetenskapsbeoefening van die voormalige Potchefstroomse Universiteit vir Christelike Hoër Onderwys geleë is. aanbied. In plaas van om lig te bring deur lewende en kragtige kontak met die wêreld, hou die Skrifgebruiker hom-/haarself blind vir die komplekse handelingsvelde waarin mense in hierdie wêreld leef.

Awad (2008:64) wys daarop hoe die kriteria vir die verkryging van betekenis in post-moderne teologie verskuif vanaf ' $n$ eksegetiese benadering (waarin betekenis verkry word deur die Bybelse teks op sigself te analiseer en toe te pas) na "meaning by virtue of performance" (waarin die lewende betekenis van die Skrif deur middel van die geleefde geloof van godsdienstige gemeenskappe opnuut uitgevoer word). Ten einde 'n perspektiefryke en verantwoordbare greep op die betekenis van die Skrif te kry, sou die wetenskaplike ondersoeker dus nie bloot kon vra: "Wat beteken die Bybelse teks van die Skrif?" nie, maar sou ook gevra moes word: "Hoe word die lewende en kragtige aard van die Skrif weerspieël in die manier waarop die kerk sy geloofsinhoude uitleef?"

Vir die praktiese teoloog wat getrou wil bly aan sy of haar Sola Scriptura-benadering tydens wetenskapsbeoefening, is die vrae wat voortspruit uit hierdie voorgestelde fokusverskuiwing duidelik:

In hoe 'n mate kan 'n ondersoek na die manier waarop die Skrif gestalte vind in die geleefde geloof van mense, wetenskaplike resultate vrywaar van oorvereenvoudigde, objektivistiese en rigiede (biblisistiese) antwoorde?

Hoekan die Skrifgetrouheidvan menslike handelingebeoordeel word, volgens 'n manier waarin dit nie 'n antroposentristiese her-interpretasie is wat die laaste sê het in die resultate van wetenskaplike ondersoek nie, maar werklik die Skrif alleen in die herskeppende impak daarvan op die oorwegings en handelinge wat uit 'n nuutgemaakte menswees voortspruit?

Ten einde hierdie vrae op ' $\mathrm{n}$ verantwoordelike manier in hierdie artikel te probeer verken, word aan die volgende aspekte aandag gegee:

Die belang daarvan om die verhouding tussen Skrif en lewende geloofsgemeenskap met die God van die Woord te verreken in die Sola Scriptura vertrekpunt van die ondersoeker;

'n Multi-dimensionele verkenning van die ondersoekveld van Praktiese Teologie met ' $\mathrm{n}$ aanduiding van die verskillende vlakke waarop Skrifgebruik ter sprake kom;

' $\mathrm{n}$ Pleidooi vir ' $\mathrm{n}$ Skrifgetroue benadering te midde van eensydighede wat in die spanningsvelde van prakties-teologiese ondersoek ten opsigte van Skrifgebruik kan plaasvind.

\section{Verrekening van die verhouding tussen Skrif en lewende geloofsgemeenskap met die God van die Woord in die Sola Scriptura vertrekpunt van die ondersoeker}

Wanneer die 16de eeuse inkleding van die Sola Scriptura vertrekpunt nagegaan word, is dit duidelik dat die reformatore nie ' $n$ een-dimensionele onderskeid tussen teks en tradisie 
getref het, asof alle vorme van tradisie noodwendig iets by die Skrif sou byvoeg of iets daarvan sou wegneem nie.

Mathison (2001:120) dui aan hoe Martin Luther en Johannes Calvyn dit juis gehad het teen ' $n$ inkleding van tradisie waarin naas die Skrif en bykomend tot die Skrif gesag aan menslike uitsprake gegee is, sonder dat hierdie uitsprake aan die Skrif getoets hoef te word:

Their complaint arose because the Roman church had completely forsaken the apostolic life and doctrine and had also theologically insulated itself against the possibility of ever being corrected by submitting itself to a higher standard of truth. By declaring herself to be infallible, Rome had, in effect, become autonomous- a law unto herself (vgl. Allert 2004: 337).

McGrath (1990:130) herinner ons daaraan dat die reformatore bewustelik teruggekeer het na die manier waarop die funksie van tradisie ingeklee is deur sommige van die vroeë Kerkvaders; 'n klassieke verstaan van tradisie waarin die gemeenskap van gelowiges, soos hierdie gemeenskap in die kerk beliggaam word, hulleself bewustelik onder die gesag van die Woord en die oproep tot gemeenskaplike lewens-heiliging wat daaruit voortvloei, gestel het:

While the notion of tradition as an extra-scriptural source of revelation is excluded, the classic concept of tradition as a particular way of reading and interpreting scripture is retained. Scripture, tradition and the kerygma are regarded as essentially coinherent, and as being transmitted, propagated and safeguarded by the community of faith. There is thus as strongly communal dimension to the magisterial reformers' understanding of the interpretation of scripture, which is to be interpreted and proclaimed within an ecclesiological matrix.

"Sola Scriptura" is die uitspraak van 'n geloofsgemeenskap wat met gewillige gehoorsaamheid vreugde vind in die bevrydende waarheid van die Skrif (vgl. Cilliers 2008:435). Hierdie gemeenskap sal die gesonde leer wat in die Skrif openbaar word ten alle koste beskerm. Dit is ondenkbaar dat daar iets in die lewe van die gemeenskap van die gelowiges by die bevrydende waarheid van die Skrif gevoeg word - iets wat hulle lewe weer onder 'n slawejuk sal indwing. Die aandrang op Sola Scriptura het dus nie met 'n kliniese, meganiese lees van die teks te doen nie, maar altyd met die lees daarvan met die oog op die oorvloed van lewe wat daardeur vir die gemeenskap van die gelowiges oopgemaak word:

The sensus literalis is not some objective, disinterested reading of the text apart from the use of Scripture in the church, but is rather the dynamic, ruled consensus of the Christian community as it has wrestled with Scripture through the years and continues to wrestle with Scripture today (Campbell 1997:90; vgl. Hays 2008:90).

Dit is belangrik om daarop te let dat die Skrifhantering van die gemeenskap van gelowiges organies ingebed is in gemeenskap met die God wat Homself in die Skrif openbaar. Dit is nie 'n kwessie van ' $n$ outonome gemeenskap wat deur middel van kreatiewe re-interpretasie op die eie verstaanshorison aangewese is vir wat dit beteken om in die konkrete menslike lewe deur die Skrif alleen gerig te word nie. Dit is nie die gemeenskap van gelowiges wat die Skrif relevant moet maak met selfstandige verbeeldingskrag nie, maar dit is die stem van God wat in die Skrif aan die woord kom waardeur nuwe lewe onder leiding van die Gees vir die gelowiges oopgemaak word:

An increasing number of people draw the conclusion that communities created and authorized by these texts (scripture - FWdeW) are summoned and permitted to live, act, and hope in different and dangerous ways, and authorized by a different voice that is heard in the text, even if that voice cannot easily be accommodated in the conventional categories of academic investigation (Brueggemann 2005a:6; 2011:239).

Die gemeenskap van gelowiges kan alleen onder die herskeppende werking van die Heilige Gees tot ' $n$ besef kom van die bevrydende waarheid wat in die Skrif opgesluit is. Deur die innerlike getuienis van die Gees word die mens oortuig van die waarheid wat in die Skrif oopgesluit word en word die beperkinge waarin menslike redenasies en voorstellinge vasgevang is, deurbreek. Die hart word deur die getuienis van die Gees vrygemaak om die hemelse majesteit van die lewende God waar te neem en in die geloof tot die oortuiging te kom dat die Drie-enige God werklik is soos wat Hy Hom in die Skrif openbaar (Calvyn Institusie (1559) 1.7.4; Kim 2003:172; vgl. Baars 2004:674; Boulton 2011:98-111).

Skrifgebruik vanuit die Sola Scriptura- geloofsvertrekpunt bring die gelowige Bybelleser nie bloot in kontak met ' $n$ teks (swart letters op wit papier nie) waaruit objektiewe waarhede deur meganiese ontleding van die teks afgelei moet word nie. Die verhouding tussen Skrif en Woord van God is van groot belang. Dit bestaan daarin dat die Skrif ons in lewende kontak met die God van die Woord bring. Die Skrif is die opgetekende gestalte van die Woord van God. Dit is ' $\mathrm{n}$ betroubare getuienis en ' $n$ helder lens (bril) waardeur ons tot ` $n$ relasionele kennis gebring word van die God,

- $\quad$ wat deur sy skeppingsmagtige en voorsienigheids- Woord alles in die skepping tot stand gebring het en dit steeds onderhou;

- wat deur sy herskeppende Woord besig is die mense waaroor Hy Hom ontferm en die wêreld waarin hulle ingebed is te bevry van verganklikheid;

- wat deur sy vleesgeworde Woord, Jesus Christus, sy liefde vir ons ondubbelsinnig duidelik maak, ons onlosmaaklik aan Hom verbind en al die gestaltes van ons menswees volgens die denke, hart en wil van Christus nuutmaak;

- $\quad$ wat deur sy gepredikte Woord nuwe lewe in dooie harte wek (vgl. Vorster 2012:7; Heyns 1977:9; Pieterse 1979:86; Vanhoozer 2002:200; Boulton 2011:96).

Zimmermann (2004:318) kombineer trinitariese met inkarnasionele teologie in die uitwerk van 'n hermeneutiek 
waarin ons beperkte en eiesinnige verstaan in ' $\mathrm{n}$ lewende verhouding met die vleesgeworde Logos deurbreek en verruim word:

Complemented by the doctrine of Trinity, incarnational theology offers an ontology that places being-incommunity at the heart of reality and gives ethical transcendence definite contours in the divine kenotic and redemptive events of cross and resurrection. By becoming human, utter transcendence becomes graspable to human preunderstanding, and yet the extraordinary revealed within these forms transcends them infinitely. Our subjective impressions are always challenged and even proven wrong by the figure of Christ. No age or culture, no intellectual or poet is privileged in his knowledge of God; this is so, however, not because God is without definite content but because meaning and knowledge radiate from Christ himself rather than originate with us.

'n Sola Scriptura-geloofsvertrekpunt het dus in wese daarmee te doen dat dit God self en God alleen is wat deur sy Woord- soos dit betroubaar opgeteken is in die Skrif- met reformatoriese krag ons wanvoorstellings en gestolde lewe deurbreek, ons tot ware kennis bring en die volheid van lewe wat Hy vir ons in gedagte het, oopmaak.

Skrifgebruik wat deur die Sola Scriptura-vertrekpunt bepaal word, sal dus wesenlike verskil van ' $\mathrm{n}$ biblisistiese gebruik, waarin die Skrif letterlik, meganies, a-histories en in geslotenheid hanteer word:

Sola scriptura is not meant as solo scriptura because it is not a notion of exclusivism. It means a hermeneutical practice performed throughout the history of the church by the power of the Spirit. It was meant to help the community re-enact its belief in God and proclaims his redemption in a lively, influential and meaningful way (Awad, 2008:75; vgl. Vorster 2012:5; Frame, 1997: 272).

Wanneer daar met die Sola Scriptura-vertrekpunt gewerk word tydens wetenskaplike ondersoek sal die Skrif nie bloot formeel as ' $n$ teks hanteer word waaruit voorskriftelike beginsels afgelei word en van buite af gerig word op die vernuwing van die ondersoekveld nie. Die Skrif sal ook hanteer word as 'n ontsluitingspunt waardeur elke gedagte, elke motief en elke handeling van die gelowige ondersoeker onder leiding van die Gees in lewende gemeenskap met Christus gestel word en daarmee die eie denke gewilliglik oopgestel word om volgens Skrifbepaaldheid gevorm te word. In afhanklikheid van die reformatoriese krag wat van Christus self kom, sal disintegrerende en deformerende kragte wat in die ondersoekveld werksaam mag wees (en duidelik in stryd met die Skrif is), deskriptief ontbloot word en sal die vorming van normatiewe teorie daarop gerig wees dat die volheid van die lewe wat God in Christus vir ons gee, opnuut in die ondersoekveld deurbreek (vgl. Hays, 2008: 90).

\section{'n Multi-dimensionele verkenning van die ondersoekveld van Praktiese Teologie met 'n aanduiding van die verskillende vlakke waarop Skrifgebruik ter sprake kom}

In kontemporêre besinning rondom die wese en taak van Praktiese Teologie, word ' $\mathrm{n}$ meer omvangryke ondersoekveld vir hierdie teologiese dissipline gevisualiseer; ' $\mathrm{n}$ dissipline wat daarvoor bekend is dat dit gereeld die eie dissiplinêre matriks in heroënskou neem (vgl. Firet 1987:260). Waar Praktiese Teologie tradisioneel gefokus het op kerklike handelinge (soos dit onderskeidelik ondersoek word in dissiplines soos homiletiek, liturgiek, pastorale wetenskap en kategetiek), word al hoe meer in 'n rigting beweeg om ook die geleefde geloofshandelinge van individuele gelowiges/ geloofsgemeenskappe en die impak van religieuse handelinge op die samelewing (soos wat dit byvoorbeeld in kontekste van HIV en VIGS, armoede, korrupsie en volhoubare ontwikkeling ter sprake kom) by die ondersoekveld van hierdie teologiese dissipline te betrek (Dreyer 2012:511; Ballard 2012:164; Campbell 2000:86). Daar kan dus gesê word dat Praktiese Teologie besig is om in ' $n$ rigting te ontwikkel waarin nie alleen gefokus word op dit wat nodig is om bedienaars van die Woord te vorm vir hulle dienswerk in die kerk nie, maar ook op die kontekste waarin hierdie dienswerk in die kerk en koninkryk van God bedien moet word en uitgeleef moet word.

Dit is egter nie alleen ten opsigte van die omvangrykheid van die ondersoekveld nie, maar ook ten opsigte van die diepte van die ondersoek en die teologiese kwaliteit van die ondersoek waaroor Praktiese Teologie homself moet verantwoord:

In die tweede helfte van die zoste eeu is Praktiese Teologie al hoe meergetipeeras' $n$ handelingsteoretiesewetenskap. Dingemans (1996:42) voer die (teologiese) handelingswetenskaplike benadering terug na die opkoms van die sosiale wetenskappe. In aansluiting by die sosiale wetenskappe is onderskeid getref tussen die beskrywende en verklarende dimensie enersyds (soos dit byvoorbeeld by sosiologie en psigologie voorkom) en die beïnvloedende of normatiewe dimensie andersyds (soos dit byvoorbeeld in pedagogiek en psigoterapie ontplooi word) (Firet 1987:28-44). Die praktiese teologie probeer albei aspekte verdiskonteer: enersyds is dit beskrywend en verklarend en andersyds ondersoek dit wyses waarop mense in die praksis met die normatiwiteit van die Christelike geloof omgaan en die wyse waarop die praksis op grond van die geloofsvisie preskriptief verbeter kan word (Mager 2012:258).

Die handelingswetenskaplike benadering is egter nie sonder kritiek in die akademiese gemeenskap opgeneem nie. Enersyds is daarop gewys dat ' $n$ handelingswetenskaplike benadering die ondersoek sou kon begrens tot die uiterlike dimensie van menslike handelinge, sonder dat die onderliggende voorveronderstellings, interpretasienetwerke en spanningsvelde verreken word (Dingemans 1996:45). Andersyds is daarop gewys dat die antroposentriese fokus van die handelingswetenskaplike benadering die teologiese kwaliteit van die wetenskapsbeoefening in gedrang kan bring. Omdat op die sigbaar-empiriese dimensie gefokus word, kan die hooffokus wat in ' $\mathrm{n}$ teologiese besinning 
rondom handelinge ter sprake behoort te kom, naamlik God se inisiatief en menslike reaksie daarop, op die agtergrond verdwyn (Mager 2012:255; vgl. Bohren 1975).

Daarom was dit nodig dat die dieptevlak van praktiesteologiese ondersoek gekwalifiseer word. In ' $\mathrm{n}$ poging om gevolg te gee aan dit wat onder die oppervlakte van menslike handelinge geleë is, is aansluiting gesoek by die hermeneutiese wetenskappe. Die begrip "werklikheid" is vir ondersoekers wat met die hermeneutiese benadering werk, nie soseer ' $n$ feitelike, objektiewe gegewenheid (empirie!) nie, maar 'n menslike konstruksie of interpretasie, wat ontstaan uit wisselwerking tussen visie en realiteit. Ons sien dinge en doen dinge op grond van "n "blik", "n "vooroordeel", "n "paradigma" of "interpretasie-netwerk", waarbinne ons werklikheid verstaan, vorm, transformeer en verander (Dingemans 1996:46). Ten einde gevolg te gee aan die manier waarop die handelende God teenwoordig is op die dieptevlak van die ondersoekveld, was dit nodig om motiewe waarom mense op 'n sekere manier optree, bewustelik te ondersoek vanuit die geloofsverankerdheid daarvan/ gebrek aan verankerdheid daarvan in God:

The notion "faith" reminds us of the fact that the relationship with God, the actual practicing of religion and the various connecting activities such as prayer and holy communion, denotes something in the real world that could not be captured sufficiently in social or psychological categories but presupposes a divine- human relationship (Pleizier 2010: 4,5; vgl. Immink 2005: 21-42).

Pieterse (2009:254) wys ook op die belang daarvan om praktiesteologiese ondersoek in die kader van geleefde geloof te plaas. Dit gaan in geleefde geloof om die belewing van die genade, ontmoeting met God en die lewende persoonlike verhouding met Hom. Dit gaan om 'n eksistensiële ontmoeting met God waarin die mens met sy totale geestesvermoë (verstand, gevoel, wil) gemoeid is. God is nie alleen voorwerp van die geloof nie (objektief), maar ook Subjek van spreke en handelinge.

Wanneer daar tussen ' $\mathrm{n}$ oppervlakte-dimensie en dieptedimensie onderskei word in die manier waarop ' $\mathrm{n}$ ondersoekveld benader word tydens prakties-teologiese ondersoek, sou vanuit ' $n$ Sola Scriptura-benadering aangetoon moet word dat Skrifgebruik nie tot die oppervlakte- dimensie beperk kan word nie: Die gebruik van die Skrif op die oppervlakte-dimensie van die ondersoekveld word deur Ballard en Pritchard (2006:129) soos volg beskryf:

The most basic form of theological reflection is that which operates in a linear mode whereby the Christian asks what biblical material- narrative, teaching, parable, lawcode, poetry, prophecy- seems particularly relevant to the situation under review. When a connection has been made, biblical wisdom and authority give the necessary insights into the current issue.

Op hierdie vlak word die Skrif in 'n ongekompliseerde beweging preskriptief op die konteks gerig. Maar wanneer Skrifgebruik tot hierdie vlak beperk word, loop dit die gevaar om in oorvereenvoudigde, objektivistiese en oppervlakkige aanwending van die Skrif te ontaard:

It is in danger of making a hermeneutical leap from the biblical 'horizon' to the current situation without taking sufficiently seriously the complexity of other descriptions of the contemporary social order. In an extreme form this approach may even implicitly locate God in a book, a church or a lecture room and disregard the conviction of faith that God will be found already at work in ambiguities and struggles of the modern world (Ballard \& Pritchard 2006:130; vgl. Hermans \& Moore 2004:1).

Dit is daarom nodig dat die Skrif ook in die diepte-dimensie van die ondersoekveld ter sprake gebring word, in die sin dat die wetenskaplike deur die lens van die Skrif onder leiding van die Gees 'n verruimde en verskerpte blik verkry op die manier waarop God in ons leefwêreld handel en hoe verblydend dit aan die een kant is wanneer mense sy genade in die geloof omhels en hoe bedroewend dit aan die ander kant is wanneer hulle hulleself daarteen verhard. Bohren (1996:59) lewer kritiek teen 'n soort Skrifgebruik waarin die Bybelse teks bloot by wyse van menslike tegnieke ontleed word, sonder dat die verruimde visie wat deur geloofswaarneming oopgemaak word ook ter sprake gebring word. Hy sluit aan by die gedagte van Calvyn dat die oë van die geloof meer waarneem as die sintuiglike oё (vgl. 2 Kor. 4:18):

It is essential for the primary point of view to see the invisible and be astonished by newly found things. A servant of the new covenant (2 Cor. 3.6) will receive eyes that see more than other optics. "Divine power" of the new creation is primary, whereas the "human ability" of literary arts is secondary. In order to find out something about the quality of knowledge one must prove its origin. One has to examine its spirit to see whether it represents God`s power or human ability or, more precisely, whether knowledge serves life or death.

Skrifhantering wat nie alleen op die oppervlakte van die ondersoekveld gerig is nie, maar ook die onderliggende diepte-dimensie verreken, kan wesenlik daartoe bydra dat die teologiese kwaliteit van prakties-teologiese ondersoek versterk word en dat daar tot die wese van onderliggende spanningsvelde deurgedring word.

\section{'n Pleidooi vir ' $n$ Skrifgetroue benadering te midde van eensydighede wat in die spanningsvelde van prakties-teologiese ondersoek ten opsigte van Skrifgebruik kan plaasvind}

Een manier ${ }^{2}$ waarop die dieptevlak van prakties-teologiese ondersoek verken kan word, is om kennis te neem van

2. Met hierdie formulering gee die outeur te kenne dat posisionering tydens vorming van verhoudingsnetwerke (met twee teenoorgestelde pole en `n integratiewe faktor in die middel) slegs een manier is waarop die dieptevlak ondersoek word. Die outeur wil dus nie sy bydrae as `n alles-omvattende model aanbied nie.

dx.doi.org/10.19108/koers.80.1.2205 
die spanningsvelde waarin handelinge voltrek word en posisionering tydens die vorming van verhoudingsnetwerke plaasvind. Hierin kan insigte vanuit die aangrensende wetenskappe van groot waarde wees vir prakties-teologiese wetenskapsbeoefening.

Die sisteemteoretiese insigte waarmee in Sosiologie gewerk word, kan byvoorbeeld lig werp op die manier waarop mense geneig is om hulleself te posisioneer binne die verhoudingsnetwerke van sosiale sisteme waarin hulle lewens ingebed is (Noble 2000:172; Bausch 2012). Louw (2005:24-41) maak gebruik van die insigte van sisteemteorie in ' $n$ poging om houdings en pole te beskryf wat aanwesig is binne verhoudingsnetwerke. Hy skematiseer die polêre dinamika binne 'n verhoudingsnetwerk deur die horisontale aspek as 'n ervarings-as (met afstand en nabyheid in bipolêre verbinding met mekaar) te trek. Op die vertikale as (die normatiewe gesags-as) staan die direktiewe komponent in bi-polêre spanning met die ondersteunings-komponent. Die verhoudingsnetwerk kan siek raak wanneer gevaarsones betree word en daar disfunksionele houdings (wat ontoepaslik is vir die bepaalde bipolêre verwantskap) begin intree. 'n Persoon wie se optrede of reaksie binne die verhoudingsnetwerk deur die pool van afstand aangetrek word, se optrede kan radikaliseer in weerstand/ onsensitiwiteit vir die belange van ander. Beweging na die pool van nabyheid kan ontaard in versmoring/ gebrek aan kritiese objektiwiteit. Op die vertikale as ontwikkel verhoudingspatologie wanneer direktiewe leierskap ontaard in outoritêre dominering en ondersteuning ontaard in manipulasie.

Wat is die implikasies van hierdie sisteemteoretiese insigte vir Skrifgebruik in prakties-teologiese ondersoek? Wanneer 'n ondersoeker (wat byvoorbeeld normatiewe merkers wil aandui vir die besluitnemingsproses van ' $n$ kerklike vergadering) die Skrif slegs op die oppervlakte van die ondersoekveld rig, word die gevaar van een- dimensionele Skrifgebruik geloop. Die Skrif sou dan bloot formeel gerig word op wat die kriteria behoort te wees vir 'n verantwoordelike besluit, sonder dat dit ook krities gerig word op die onderliggendegesindhedewaarmeebesluitnemers hulleself posisioneer in die verhoudingsnetwerk wat in die spanningsveld van die vergadering na vore tree (vgl. De Wet \& Kruger 2010).

In plaas van om bloot een-dimensionele normatiewe riglyne te gee vir hoe besluitneming wat bevorderlik is vir kerklike eenheid behoort te lyk, sou 'n verkenning van die dieptevlak 'n perspektiefryke blik op die navorsingsprobleem kon bied. In die verkenning van die probleem sou byvoorbeeld gesien kon word dat gebrek aan ' $\mathrm{n}$ eenvormige besluit nie bloot formeel te doen het met verskillende interpretasies van normatiewe bronne wat met die oog op besluitneming geraadpleeg is nie. Daar sou op die dieptevlak van die probleemveld gesien kon word hoe disfunksionele houdings na vore tree wanneer gesonde/gebalanseerde bipolêre spanning begin disintegreer. Besluitnemers wie se gedagtes en motiewe ingetrek word deur ' $\mathrm{n}$ direktiewe en afstandelike konfigurasie, kan geneig wees om ' $\mathrm{n}$ rigiede en ongenaakbare standpunt in te neem. Besluitnemers wie se gedagtes en motiewe deur ' $\mathrm{n}$ deelnemende en akkommoderende konfigurasie bepaal word, kan geneig wees om ' $n$ standpunt in te neem waarin die mening wat die aanvaarbaarste sou wees vir die samelewing waarin die denksisteem ingebed is, met manipulerende druk aangewend word. Insig in die polarisasie wat besig is om vorm aan te neem in hierdie spanningsveld, gee ‘n diepteblik op die disintegratiewe en onverkwiklike kragte wat hier aan die werk is. Dit word duidelik dat die Skrif ook op die gesindhede wat hier aan die werk is gerig moet word ten einde te onderskei watter kragte tot disintegrasie (en dood) lei en watter kragte tot integrasie (en lewe) lei. Nie alleen die Skriftuurlike gronde waarvolgens besluite geneem word nie, maar ook die Skrifbepaalde gesindhede waarmee besluite geneem word, behoort in prakties-teologiese Skrifgebruik ter sprake te kom.

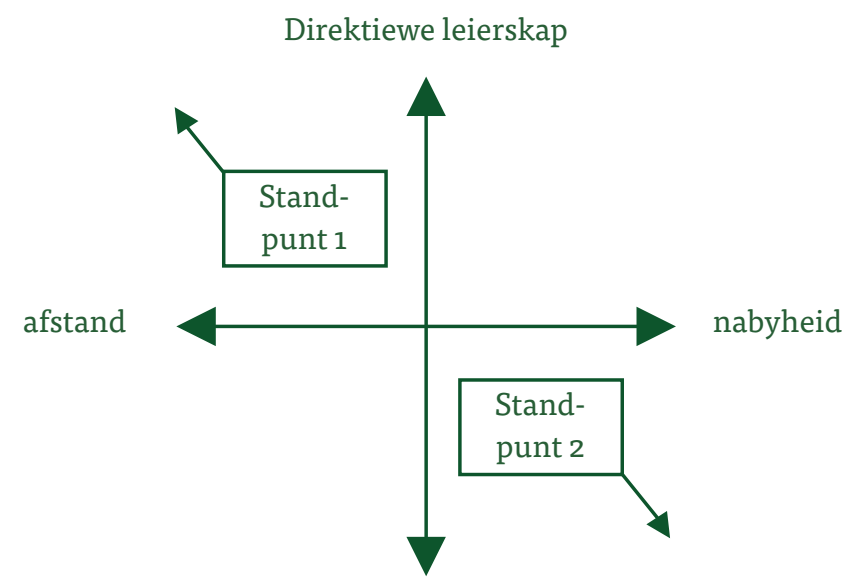

Wedersydse ondersteuning

Figuur 1: 'n Voorbeeld van polarisasie wat in die spanningsveld van kerklike besluitneming kan ontwikkel 
As ' $n$ tweede voorbeeld van hoe vorming van verhoudingsnetwerke betrek behoort te word by die verstaan van kommunikatiewe handelingsvelde, kan op die navorsingsterrein van Homiletiek na Brueggemann (2005b) se inkleding van die sogenaamde "triangulasie"-konsep verwys word. Brueggemann ontplooi sy inkleding van hierdie konsep na aanleiding van Bowen (1985) se gesinsterapeutiese navorsing rakende die vorming van triangulasie in verhoudingsnetwerke tussen gesinslede; in gesinne se verhoudingsnetwerke word oneindige patrone van "twee-teen-een" gevorm. In die verhoudingsdinamika wathieruitvoortvloeiprobeer elkelidvan die familie alles in sy of haar vermoë om nie in die blootgestelde posisie van die uitgesonderde een vasgevang te raak nie. Die ander twee lede van die driehoekige verhoudingsnetwerk posisioneer hulleself bewustelik teenoor die uitgesonderde een. Ongesonde vorme van triangulasie kan tot 'n oneindige herhaling van manipulerende magspeletjies aanleiding gee (vgl. Regina 2011:16). Brueggemann (2005b:496) probeer om die triangulasie tussen Bybelse teks, prediker en hoorders op ' $n$ manier in te rig waarin ' $n$ gesonde verhoudingsnetwerk tot stand gebring word; 'n verhoudingsnetwerk waarin daar gevolg gegee word aan die gesag van die teks:

I suggest, then, let the pastor triangle with the congregation against the text, so that the text is the lone member of the triangle, and then see how the text lives as the odd one in such a triangle. I believe that the textual conversation in the church could be very different if pastors were able to begin with the awareness that the text is too offensive for the people, but it is also too offensive for the pastor, because it is the living Word of God, and it pushes always beyond where we want to go or be. Such a posture honors the great authority of the text. It also acknowledges our restless resistance to the text and lets us enter into dangerous textual conversation with someof our best friends as allies.
Hierdie gedagtegang van Brueggemann illustreer hoe nodig dit is dat die Skrif in die uitvoer van die normatiewe taak van prakties-teologiese ondersoek rakende die wese van prediking nie alleen oppervlakkig en lineêr gerig moet word op dit wat die ideale inrigting van Skrifgetroue Woordverkondiging behoort te wees nie. Dan sou die ondersoeker die gevaar loop om slegs op ' $n$ een-dimensionele manier aan te dui dat die ideaal vir suiwer Woordverkondiging daarin bestaan om volgens die bedoeling van die Gees tot die harte van die gelowiges deur te dring, sonder om die onderliggende motiewe waarmee die prediker en die hoorders hulleself in 'n bepaalde konfigurasie met mekaar en die met die teks posisioneer, in ag te neem.

Op die dieptevlak van die ondersoekveld kan die navorser tot die besef kom van disintegratiewe kragte wat in die werklikheid van die homiletiese proses plaasvind wanneer die kommunikatiewe driehoekige verhoudinge tussen die teks, prediker en hoorders versteur word. Daar kan byvoorbeeld waargeneem word dat die prediker homself of haarself op so ' $\mathrm{n}$ manier met die teks verbind dat die verhouding met die hoorders begin disintegreer. Weens 'n hoë agting vir die integriteit en gesag van die teks word sterk op die struktuur van die teks en die oorspronklike betekenis daarvan gefokus. Deur versigtige en kliniese eksegese word die struktuur van die teks verken en word groot moeite gedoen om in die verklaringsproses die letterlike en historiese betekenis daarvan behoue te laat bly. Sonder dat die prediker dit besef, kan hierdie fiksasie op die letter van die teks die betekenis van die Woord vir die hoorders in die lug laat bly hang in die vorm van algemene toepassings en gestolde waarhede. Die hoorders neem wel kennis van 'n suiwer waarheid, maar dit vat nie grond in hulle konkrete leefwêreld nie. (vgl. De Wet 2011:66; De Leede \& Stark 2013:97-98)

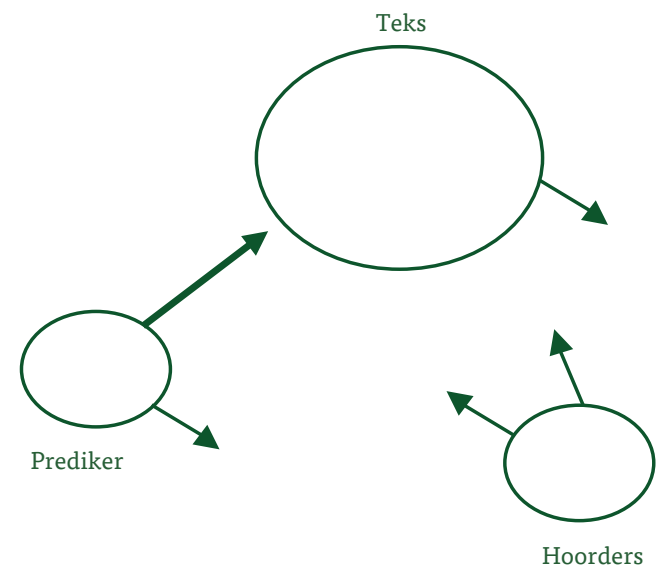

Figuur 2: In die manier waarop die prediker hom of haar oriënteer ten opsigte van die teks disintegreer die driehoekige verhouding met die hoorders

In 'n ander geval kan die prediker homself of haarself so met die hoorders verbind, dat die aktiewe stem van die teks na die agtergrond verskuif. Die prediker word so in die wêreld van die hoorders ingetrek, dat hy of sy daarop gefikseer raak om aanklank by die hoorders te vind. Die realiteite waarmee die hoorders te doen kry in hulle leefwêreld en die volle impak wat dit op hulle menswees maak, staan in die kollig. Die prediker probeer sensitief daarvoor wees om aan elke mens die tyd en 
ruimte en vryheid te gee om komplekse sake in sy of haar lewe in selfstandige wisselwerking met die teks te verwerk. Hierdie manier van omgaan met die teks kan daartoe aanleiding gee dat slegs 'n relatiewe/metaforiese betekenis aan die teks toegeskryf word en dat die teks verhinder word om met ' $\mathrm{n}$ perspektief wat verrassend meer is as wat ons kan antisipeer in die lewe van die hoorders deurbreek (vgl. De Wet 2012:6).

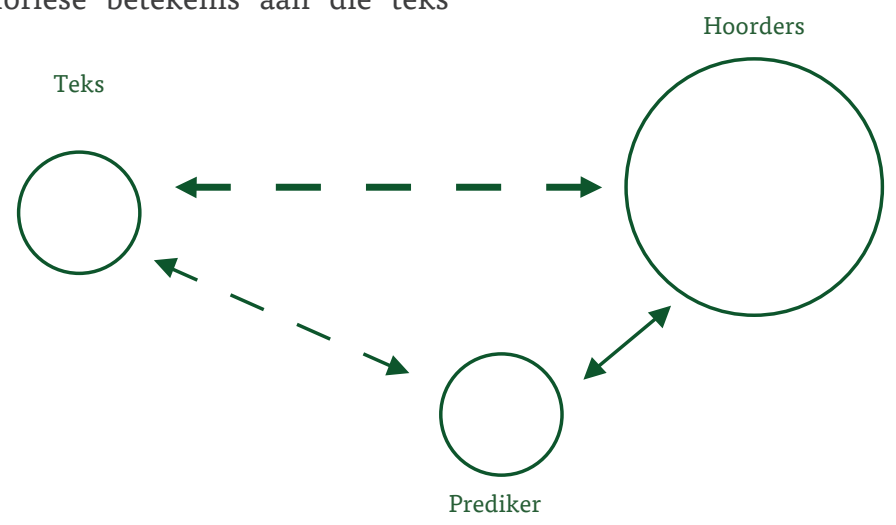

Figuur 3: In die manier waarop die prediker hom of haar verbind met die hoorders, vervaag die eie stem van die teks

Wanneer die dieptevlak van die ondersoekveld vanuit die Sola Scriptura-standpunt benader word, sal die spanningsveld ten diepste gevisualiseer word in terme van die spanning tussen self-sentriese en a-sentriese lewe; tussen 'n self-handhawende/ self-aktualiserende lewensgerigtheid (asof ons lewe in ons eie hande sou wees) en 'n lewensgerigtheid waarin daar in afhanklikheid van die genade van God alleen geleef word met die diepe wete dat die lewe 'n geskenk is wat uit die hand van die drie-Enige God kom (vgl. Webster 2003:228). Dit is deur die Skrif alleen dat ons in lewende geloofsgemeenskap met Christus die verskil kan sien tussen ' $n$ lewensgerigtheid wat in selfgerigtheid tot die dood lei en ' $n$ lewensgerigtheid wat in God-gerigtheid tot die lewe lei.

Skrifhantering waarin die hart van die probleemveld ontsluit word, het daarmee te doen dat die evangelie van die gekruisigde en opgestane Christus (nie as ' $n$ blote voorskriftelike teks nie, maar in lewende gemeenskap met Christus self wat deur sy Gees in ons harte leef) daarin bedien word. Deur die bediening van die Woord word die spanningsveld in die ruimte van die nuwe verbond, waarvan Christus die Middelaar is, ingetrek. In die verbondsruimte, waarin Christus op grond van sy lyding, dood en opstanding versoenend teenwoordig is, kan kragte wat tot vervreemding, disintegrasie en dood aanleiding gee, nie langer heers nie (Rom. 5:15; 2 Kor. 5: 19-20; vgl. De Wet 2011:70). In die verbondsruimte waar Christus teenwoordig is, word die Skrifhanteerder in 'n hermeneutiese sirkel geplaas tussen die volheid van die opstandingslewe wat deur God gegee word en die mate waarin daar kragte in ons menslike lewe aan die werk is wat hierdie opstandingslewe wil verhinder om met die volle krag en impak daarvan deur te breek. In sy hart het hierdie hermeneutiese sirkel te doen met 'n soeke na wat dit beteken om waarlik mens te wees. Alleen in 'n eksistensiële hermeneutiese sirkel tussen die self en God, kan die verskil gesien word tussen die heerlikheid wat uit ' $n$ herstelde verhouding met God voortvloei vir menswees en die ellende wat uit `n ontwrigte verhouding met Hom voortvloei (vgl. Zimmermann 2004:272).

In hierdie inkleding van die Sola Scriptura- benadering sal die ondersoeker nie alleen bewus word van maniere waarop die Skrif in die handelinge van mense in die ondersoekveld verhinder word om met die volle krag daarvan deur te breek nie. Die ondersoeker sal ook in sy of haar eie manier van Skrifhantering gekonfronteer word met onderliggende gesindhede waarin die Skrif aan bande gelê word of verduister word of sodanig normatief aangelê word dat dit mense van mekaar vervreem eerder as om hulle tot eenheid in Christus te lei:

Die ondersoeker sal bewus word van maniere waarop die Skrif so hanteer word dat die reikwydte van die afleidings wat daaruit gemaak word in ' $n$ denksisteem gegiet word, wat bloot daarop gerig is om die status quo te bewaar; ' $n$ sisteem waarin die Woord op ' $n$ veilige afstand van die lewe gehou word en ons nie met die lewensveranderende impak daarvan gekonfronteer hoef te word nie. In sy 1971-rede, "De aktualiteit der prediking in het licht van het 'Sola Scriptura' der Reformatie", het Trimp (1983 [1971]:7) reeds daarop gewys dat die kerk nie kan lewe deur ' $\mathrm{n}$ objektivistiese prediking nie; ' $\mathrm{n}$ soort prediking wat bestaan in ' $\mathrm{n}$ rasionele uiteensetting van die inhoud van ' $n$ teks in sy historiese verband waarin die gemeente bloot as toeskouers betrek word. In ' $\mathrm{n}$ objektivistiese preek is daar 'n ongeoorloofde distansie tussen preek en hoorder. Die Woord bereik die hart nie. Die bediening van die Woord verskrompel tot ' $n$ kragtelose eksegetiese bedrywigheid en die kerugma gaan op in dooie skrifgeleerdheid. Brueggemann (2005b:497) wys daarop hoe die Bybelse teks in ' $n$ teologiese sisteem geïsoleer kan word met die resultaat dat dit sy gevaarlike stem verloor. In die proses dien die teks bloot as ' $n$ eggo vir een of ander geslote intellektuele artikulasie waarin die lewensveranderende implikasies wat in die teks opgesluit is, nie toegelaat word om te ontsluit nie. Hierdie soort van Skrifgebruik kan in 'n vorm van Skrifmisbruik ontaard waarin die eie gestolde visie voorskriftelik op die werklikheid afgedwing word (vgl. Campbell 2002:84). Wanneer 'n teoloog sy of haar ondersoekveld met hierdie soort Skrifgebruik benader, is dit duidelik dat daar geen reformatoriese krag uit die ondersoek sal kan voortvloei nie.

Aan die ander kant van die spektrum sal die ondersoeker ook gekonfronteer word met die onhoudbaarheid van 
'n soort Skrifgebruik waarin die Skrif tot 'n on-voorskriftelike gespreksgenoot in 'n gelyk-vlakkige dialoog met die hedendaagse konteks afgeskaal word en die krag vir die oopmaak van vernuwende perspektiewe in `n soort kreatiewe reïnterpretasie gelokaliseer word; 'n kreatiewe handeling waarin die ondersoeker self ' $\mathrm{n}$ toegangspoort moet skep vir die Skrif ten opsigte van die relatiewe en relevante betekenis daarvan in die konstruksie van nuwe kennis . In hierdie verband kan na McClure (2001:149) se tipering van prediking as "other-wise preaching" verwys word. In "other-wise preaching" is die fokus voluit op die lewe van gemarginaliseerdes ("others"); mense wie se nood en behoeftes in konvensionele prediking nie in die brandpunt geplaas is nie. Predikers moet versigtig wees dat daar - op die manier waarop die gewone gesagsbronne (waaronder die Skrif die vernaamste is) ontplooi word - nie ' $\mathrm{n}$ onderdrukking plaasvind van die uniekheid van andersoortige mense se behoeftes en prediking van die Woord gevolglik in geslotenheid stol nie. Wilson (2004:140) dui aan dat hierdie benadering van McClure daarop neerkom dat die Skrif op ' $n$ manier aangewend word waarin die brandpunt by die sosiale fokus lê en dat die openbaring-gedagte in die proses op die agtergrond vervaag.

As ' $n$ voorbeeld van ' $n$ benadering waarin die Skrif by wyse van kreatiewe herinterpretasie op die hedendaagse konteks gerig word, kan na Bond (1999:40-42) se metaforiese Christologie verwys word. In hierdie benadering word teologie se metaforiese betekenis beklemtoon en verdwyn die metafisiese betekenis (openbarings-werklikheid) op die agtergrond. 'n Metafoor moet dan nie deur die letterlike betekenis daarvan ingeperk word nie. Die metaforiese betekenis van Jesus se opstanding word dan by wyse van kreatiewe reïnterpretasie geaktualiseer wanneer dit betrek word op situasies waarin mense aangemoedig word om kragte wat tot dood en vernietiging lei (byvoorbeeld 'n krag soos geweld) te oorwin deur die krag van geweldlose opstandingslewe; Deur geweldlose opstandingslewe kan die kwaad deur die goeie oorwin word. In hierdie benadering gaan dit nie daaroor of Jesus werklik uit die dood opgestaan het en nou lewend teenwoordig is nie. Dit gaan dan eerder oor die metaforiese krag van die opstandings-gedagte soos dit in die konkrete werklikheid waarmee mense daagliks te doen het, moet deurbreek; dit gaan dan oor die kreatiewe stappe wat geneem moet word om nuwe energie los te maak in ' $n$ gemeenskap wat deur vernietigende kragte bedreig word (vgl. Wilson, 2004:143,144). Hierteenoor maan Campbell (1997:201):

...when the unique, unsubstitutable subject, Jesus of Nazareth, evaporates into general human experience, one would rarely expect anything very radical- or even very interesting- to be preached. On the other hand, if preachers would linger with the identity of Jesus before moving too quickly to his meaningfulness, they might be surprised.

Dat disintegrerende kragte wat aan die werk is in die spanningsvelde wat hier bo beskryf is, kan alleen oorbrug word deur die integratiewe teenwoordigheid van Jesus Christus. Skrifgebruik waarin die lewende teenwoordigheid van die gekruisigde en opgestane Jesus Christus hermeneuties bedien word, sou nodig wees om met reformerende krag beide geslote, inperkende sisteme te deurbreek, sowel as koers aan te dui vir soekende spiraalgange.

Verantwoording ten opsigte van Skrifgetroue hantering van die Skrif in prakties-teologiese spanningsvelde ten opsigte van die vorming van disintegrerende polariteit wat daarin mag ontstaan, sou soos volg voorgestel kon word:
Die Skrif as on-voorskriftelike gespreksgenoot in ' $n$ gelyk-vlakkige dialoog
Die Skrif as toegangspoort vir geloofsverankering in die gekruisigde en opgestane Christus wat lewend by sy kerk is en in hierdie wêreld optree
Die Skrif as bron van gesag vir 'n voorskriftelike sisteem

Die Skrifhanteerder gebruik die Skif as normatiewe bron vir die regverdiging van die eie teologiese sisteem leiding van die Gees as ontsluitingspunt die bediening van die versoeningskrag wat uit die teenwoordigheid van die lewende Christus voortvloei

Die hermeneutiese proses word ontsluit deur die disintegrasie-oorwinnende teenwoordigheid van die lewende Christus
Die hermeneutiese proses kan stol in 'n geslote sisteem
Die hermeneutiese proses kan vasgevang raak in 'n spiraalgang waarin dit wat aanvaarbaar en haalbaar is vir antroposentristiese denke, die gang stuur

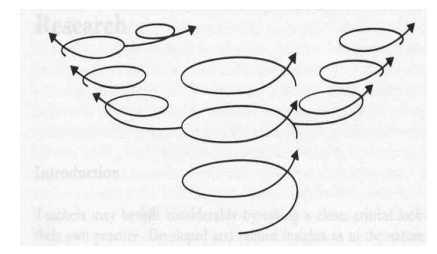

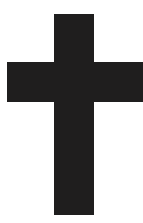

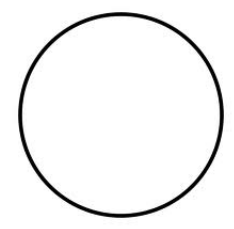

Figuur 4: Verantwoording ten opsigte van Skrifgetroue hantering van die Skrif in prakties-teologiese spanningsvelde 
Wanneer bogenoemde verantwoording ten opsigte van Skrifgetroue hantering van die Skrif in prakties-teologiese spanningsvelde verreken word, sou die Skrif in 'n konteks van kerklike besluitneming op ' $n$ manier ontplooi word waarin daar nie bloot voorskriftelik te werk gegaan word nie. Die gesindhede en die harte van almal wat betrokke is in die spanningsveld sal in lewende gemeenskap met die integratiewe teenwoordigheid van Jesus Christus gebring word. Dit sal ten diepste die manier wees waarop die disintegrerende en polariserende kragte wat aan die werk is in die spanningsveld deurbreek kan word.

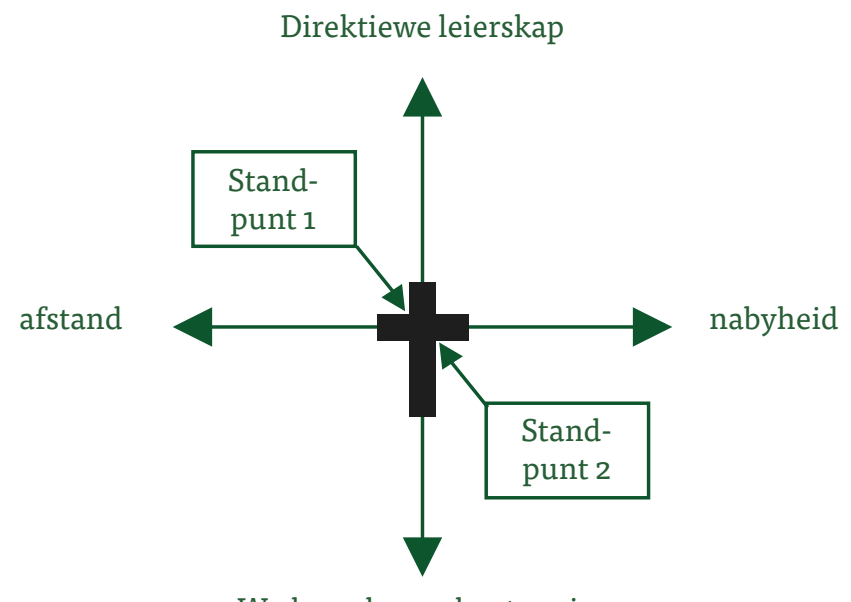

Wedersydse ondersteuning

Figuur 5: Die integratiewe krag van die teenwoordigheid van Christus in die hart van die kerklike besluitneming- spanningsveld

In die geval die ondersoek na die posisionering van die teks, prediker en hoorders in die kommunikatiewe driehoek wat tydens die homiletiese proses gevorm word, sou die Skrif ook met integratiewe krag op die dieptevlak van die proses gerig kon word. Deurdat die spanningsveld van die verhouding tussen teks, prediker en hoorder in die verbondsruimte ingetrek word (waar Jesus Christus as Middelaar van die nuwe verbond lewend teenwoordig is), word ' $\mathrm{n}$ gebalanseerde driehoek moontlik; 'n Driehoek waarin Christus self die lewensveranderende implikasies van die teks vir die prediker laat deurbreek en die prediker in staat stel om in gehoorsaamheid aan Christus as ' $n$ mede-gebrokene onder gebrokenes die liefde en geregtigheid van Christus waarheid-ontblotend en genesend te bedien in die lewe van die hoorders.

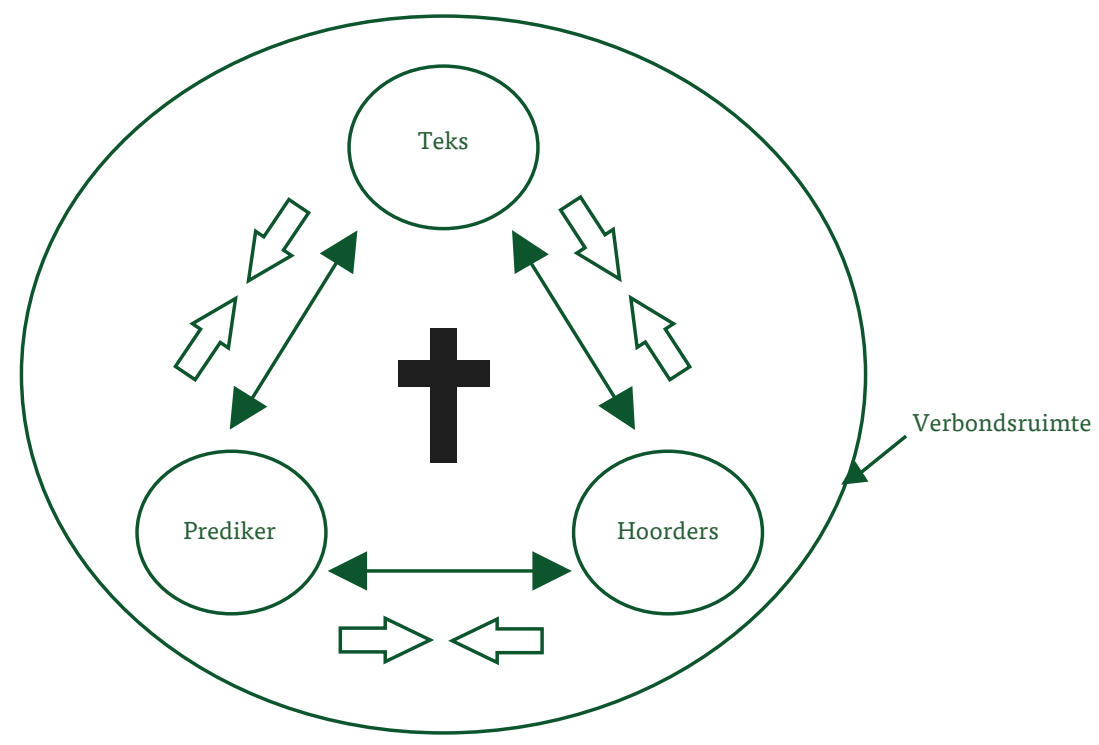

Figuur 6: In die verbondsruimte waar Christus lewend teenwoordig is, word 'n gesonde, integratiewe kommunikatiewe driehoek tussen teks, prediker en hoorders tot stand gebring 


\section{GEVOLGTREKKING}

In ‘n Solo Scriptura- benadering word daar nie alleen rekening

gehou met formele koers-aanduiding vir hoe die handelinge van mense ingerig behoort te word nie. Dit is ook die Skrif alleen wat in Skrifbepaaldheid op die dieptevlak van die ondersoekveld,

- $\quad$ elke gedagte krities oopbreek volgens die denke van Christus;

- die hart lieflik genees, sodat dit wat waargeneem word en bedien moet word in die ondersoekveld met die innige bewoënheid van Christus vervul word;

- en elke handeling wat oorweeg word, oopbuig in gewillige gehoorsaamheid aan Christus.

Op hierdie wyse kan Skrifhantering in diens van die Woord van God staan om met onbevange reformatoriese krag deur te breek in prakties-teologiese spanningsvelde.

\section{BIBLIOGRAFIE}

Allert, G.D., 2004, 'What are we trying to conserve? Evangelicalism and Sola Scriptura', The Evangelical Quarterly 76(4), 327-348.

Awad, N.G., 2008. 'Should we dispense with Sola Scriptura? Scripture, tradition and postmodern theology', Dialog: A Journal of Theology 47(1): 64- 79.

Baars, A., 2004, Om Gods verhevenheid en zijn nabijheid: de Drie-eenheid bij Calvijn, Kok, Kampen.

Ballard, P., 2012, 'The use of Scripture', in B.J. Miller-McLemore, (ed.), The Wiley-Blackwell Companion to Practical Theology, pp. 163-172, Blackwell Publishing, Chichester.

Ballard, P. \& Pritchard, J., 2006, Practical Theology in action-Christian thinking in service of church and society, SPCK, London.

Bausch, K.C., 2012, The emerging consensus in social systems theory, Springer, London.

Bohren, R., 1975, Dass Gott schön werde: Praktische Theologie als theologische Ästhetik, Chr. Kaiser, München.

Bohren, R., 1996, 'Practical Theology as a critique of knowledge', in T.G. Long \& E. Farley, (eds.), Preaching as a theological task: Word, Gospel, Scripture (In honor of David Buttrick), pp. 59-70, Westminster John Knox Press, Louisville.

Bond, L. S., 1999, Trouble with Jesus: Women, Christology, and preaching, Chalice Press, St. Louis.

Boulton, M.M., 2011, Life in God - John Calvin, practical formation, and the future of protestant theology, Eerdmans, Grand Rapids.

Bowen, M., 1985, Family therapy in clinical practice, Rowman \& Littlefield Publishers, Lanham, Maryland.

Brueggemann, W, 2005a, The Book that breathes new life- Scriptural authority and biblical theology, Fortress Press, Minneapolis.

Brueggemann, W., 2005b, 'The preacher, the text and the people', Review and Expositor 102(1): 493-506.

Brueggemann, W., 2011, Disruptive grace-Reflections on God, Scripture, and the church (Edited and introduced by Carolyn J. Sharp), Fortress Press, Minneapolis.

Calvyn, J., 1991/1992 [1559], Institusie van die Christelike godsdiens, vert. H.W. Simpson, CJBF, Potchefstroom.

Campbell, A., 2000, 'The nature of Practical Theology', In J. Woodward \& S. Pattison (eds.), The Blackwell reader in pastoral and practical theology, pp. 77-88, Blackwell Publishing, Oxford.

Campbell, C.L., 1997, Preaching Jesus: New directions for Homiletics in Hans Frei's postliberal theology, Wipf \& Stock, Eugene.

Campbell, C.L., 2002, The Word before the powers: an ethic of preaching, Westminster John Knox Press, Louisville.

Cilliers, J., 2008, "'Skrifgetrouheid" in die erediens? Kantaantekeninge by 'n kernbelydenis', In die Skriflig 42(3), 431-447.

De Leede, H. \& Stark, F., 2013, 'Protestantse preken in hun kracht en zwakheid: Een quickscan', Nederlands Theologisch Tijdschrift 67(2): 85-100.

De Wet, F.W. \& Kruger, F.P., 2010, “' $n$ Prakties-teologiese perspektief op die handeling van kerklike besluitneming: praktykteorie', In die Skriflig 44(2), 405-427.

De Wet, F.W., 2011, Hoe lieflik is die lig: 'n Verkenning van die dieptevlak van die homiletiese proses, Potchefstroomse Teologiese Publikasies, Potchefstroom. 
De Wet, F.W., 2012, 'Verrekening van die kragveld van die verbond in die inkleding van die kommunikatiewe driehoeksverhouding tussen teks, prediker en hoorder, In die Skriflig/ In Luce Verbi 46(1), 1-9.

Dingemans, G.D.J., 1996, Manieren van doen: Inleiding tot de studie van de Praktische Theologie, Kok, Kampen.

Dreyer, J.S., 2012, 'South Africa', in B.J. Miller-McLemore, (ed.), The Wiley-Blackwell Companion to Practical Theology, pp. 505-514, Blackwell Publishing, Chichester.

Firet, J., 1987, Spreken als een leerling: Praktisch-theologische opstellen, Kok, Kampen.

Frame, J.M., 1997, 'In defense of something close to biblicism: reflections on Sola Scriptura and history in theological method', Westminster Theological Journal 59(1), 269-291.

Hays, R.B, 2008, 'Reading the Bible with eyes of faith: theological exegesis from the perspective of biblical studies', in M. Root \& J.J. Buckley (eds.), Sharper than a two-edged sword - preaching, teaching and living the Bible, pp.82-101, Eerdmans, Grand Rapids.

Hermans, C.A.M. \& Moore, M.E., 2004, 'The contribution of empirical theology by Johannes A. Van der Ven: An introduction', in C.A.M. Hermans and M.E. Moore (eds.), Hermeneutics and empirical research in practical theology: the contribution of empirical theology by Johannes A. van der Ven, pp.1-20, Brill, Leiden.

Heyns, J.A., 1977, Die Kerk, N.G. Kerkboekhandel, Pretoria.

Immink, F.G., 2005, Faith: a practical theological reconstruction, Eerdmans, Grand Rapids.

Kim, M.Y., 2003, 'Reformed Pneumatology and Pentecostal Pneumatology', in W.M. Alston, Jr. \& Welker, M., (eds.), Reformed Theology- Identity and Ecumenicity, pp. 170-189, Eerdmans, Grand Rapids.

Louw, D., 2005, Die ratwerke van die menslike siel- oor volwassenheid en lewensvaardighede, Sun Press, Stellenbosch.

Mager, R., 2012, 'Action Theories', in B.J. Miller-McLemore, (ed.), The Wiley-Blackwell Companion to Practical Theology, pp. 255-265, Blackwell Publishing, Chichester.

Mathison, K.A., 2001, The shape of Sola Scriptura, Cannon Press, Moscow, Idaho.

McClure, J.S. 2001, Other-wise preaching: A postmodern ethic for Homiletics, Chalice Press, St. Louis.

McGrath, A., 1990, The Genesis of doctrine: A study in the foundations of doctrinal criticism, Blackwell, Oxford.

Noble, T., 2000, Social theory and social change, St. Martin's, New York.

Pieterse, H.J.C., 1979, Skrifverstaan en prediking-Die verhouding van Woordgebeure en verstaansgebeure by Gerhard Ebeling as antwoord op die nood van prediking, N.G. Kerkboekhandel, Pretoria.

Pieterse, HJC. , 2009, 'Prediking wat God ter sprake bring in die Suid-Afrikaanse konteks van regstellende aksie', in F.G. Immink \& C.J.A. Vos (reds.), God in een kantelende wereld: Geloof en kerk in veranderende contexten, pp.250-273, Boekencentrum, Zoetermeer.

Pleizier, T., 2010, Religious involvement in hearing sermons- $A$ Grounded Theory study in empirical theology and Homiletics, Eburon Academic Publishers, Delft.

Regina, W.F., 2011, Applying family systems theory to mediation- a practitioner's guide, University Press of America, Lanham, Maryland.

Trimp, C., 1983 [1971], De aktualiteit der prediking: In het licht van het 'Sola Scriptura'der Reformatie, Uitgeverij De Vuurbaak, Groningen.
Vanhoozer, K.J., 2002, First theology: God, Scripture and Hermeneutics, InterVarsity Press, Downers Grove.

Vorster, J.M., 2012, 'Christian ethics in the face of secularism', Verbum et Ecclesia $33(2), 1-8$.

Wilson, P.S., 2004, Preaching and homiletical theory, Chalice Press, St. Louis.

Zimmermann, J., 2004, Recovering theological hermeneutics- an incarnational-Trinitarian theory of interpretation, Baker Academic, Grand Rapids.

\section{Competing interests}

The author declares that he has no financial or personal relationship(s) that may have inappropriately influenced him in writing this article. 